\title{
PRESCRIBED FIRE IN OAK SAVANNA: FIRE FREQUENCY EFFECTS ON STAND STRUCTURE AND DYNAMICS
}

\author{
David W. Peterson ${ }^{1}$ And Peter B. Reich \\ Department of Forest Resources, University of Minnesota, 1530 N. Cleveland Avenue, St. Paul, Minnesota 55108 USA
}

\begin{abstract}
Although it is well known that fire can exert strong control on stand structure, composition, and dynamics in savannas and woodlands, the relationship between fire frequency and stand structure has been characterized in few of the world's savanna and woodland ecosystems. To address this issue in temperate oak-dominated ecosystems, we studied the effects of fire frequency on stand structure and dynamics in oak savanna and woodland stands that had been burned 0-26 times in $32 \mathrm{yr}$, in the Anoka Sand Plain region of Minnesota (USA).

Seedling densities declined with increasing fire frequency, but differentially, for northern pin oak (Quercus ellipsoidalis), black cherry (Prunus serotina), serviceberry (Amelanchier sp.), and red maple (Acer rubrum). Bur oak (Q. macrocarpa) seedling density was not sensitive to fire frequency. Frequent burning (at least three fires per decade) prevented development of a sapling layer and canopy ingrowth. Low-frequency burning (fewer than two fires per decade) produced stands with dense sapling thickets.

Reductions in overstory density and basal area from 1984 to 1995 were observed for all stands burned two or more times during that period. Basal area declined by $4-7 \%$ per year, and density declined by $6-8 \%$ per year in stands burned four or more times. Mortality rates in burned stands were higher for northern pin oak $(50 \%)$ than for bur oak $(8 \%)$. Northern pin oak mortality was highest for small trees $(<20 \mathrm{~cm} \mathrm{dbh})$ and lowest for mature trees (30-40 cm dbh); mortality increased with fire frequency. Bur oak mortality declined with increasing fire frequency.

Attempts to preserve and maintain savannas as a viable ecosystem type in this region will require a long-term commitment to restoration-based management, with prescribed fire as a central tool. Burn frequency treatments with four or more fires per decade produce similar reductions in stem density and stand basal area but may lead to unsustainable oak tree populations. Within this general range, fire frequencies at a decadal scale should be chosen to address other management objectives, including suppressing shrubs and promoting increased cover of grasses and other herbaceous species. Fire management with a long-term view may also require periodic respites to allow for new cohorts of mature oak trees.
\end{abstract}

Key words: fire frequency; LTER; oak savanna; oak woodland; prescribed burning; Quercus ellipsoidalis; Quercus macrocarpa; restoration; stand dynamics; stand structure.

\section{INTRODUCTION}

Woody structure plays an important functional role in savannas and woodlands. Trees in savannas modify the microclimate, soil water, and nutrient availability under their canopies, producing spatial heterogeneity in plant resources (Tiedemann and Klemmedson 1973, Parker and Muller 1982, Belsky et al. 1989, Weltzin and Coughenour 1990, Ko and Reich 1993, Mordelet et al. 1993). Understory plant communities often vary between tree-dominated and open patches, apparently in response to variation in plant resources (Bray 1958, Parker and Muller 1982, Weltzin and Coughenour 1990, Ko and Reich 1993, Scholes and Archer 1997, Naumburg and DeWald 1999). Trees and shrubs also

Manuscript received 14 February 2000; revised 15 May 2000; accepted 6 June 2000.

${ }^{1}$ Present address: Civil and Environmental Engineering, University of Washington, Wilcox Hall, Box 352700, Seattle, Washington 98195-2700 USA. produce spatial heterogeneity in overall net primary productivity (NPP) and in the proportions of NPP allocated above- and belowground (Grunow et al. 1980, Belsky et al. 1989, Callaway et al. 1991, Scholes and Archer 1997).

Woody structure also distinguishes savannas and woodlands from other forest and grassland communities. Savannas are commonly defined as communities with a continuous herbaceous layer usually dominated by grasses and a discontinuous layer of trees or shrubs, up to 25-50\% cover (Belsky 1990, McPherson 1997, Taft 1997, Anderson et al. 1999). Woodlands have a higher cover of overstory trees (up to 80\%) and understory communities that include a mixture of grasses, forbs, and woody plants (shrubs, vines, and tree seedlings) (Taft 1997). Together, savannas and woodlands form a structural continuum between grasslands and forests.

Fire frequency is an important factor influencing 
woody structure and stand dynamics in many temperate savanna and woodland plant communities of North America (Agee 1993, Huddle and Pallardy 1996, McPherson 1997, Anderson et al. 1999). In many areas historically occupied by savannas and woodlands, precipitation and soil moisture are sufficient to support forests (Anderson et al. 1999). High-frequency fire regimes have been credited with creating and maintaining savannas and woodlands in these areas prior to and during Euro-American settlement (Gleason 1913, McPherson 1997, Anderson et al. 1999). However, reductions in fire frequency caused by landscape fragmentation, land use change, fire prevention activities, and active fire suppression have led to significant structural changes, including increased tree density, basal area, and canopy cover (Stout 1944, Cooper 1960, Abrams 1986, Agee 1993, Faber-Langendoen and Davis 1995), and succession toward more fire-sensitive and shadetolerant overstory species (Heyward 1939, Garren 1943, Dickman 1978, Wright and Bailey 1982, Agee 1993). These changes may have important implications for wildlife habitat, biotic diversity, and risk of future catastrophic disturbance (Heyward 1939, Cooper 1960, Wright and Bailey 1982, Grundel et al. 1998).

Oak savannas were once widespread in midwestern North America, occurring primarily within an ecotonal band between tallgrass prairie and temperate deciduous forest biomes (Nuzzo 1986). Local variations in fire frequency produced by topographic barriers to the spread of fire (rivers, lakes, and bluffs) strongly influenced vegetation structure within this ecotone, creating a mosaic of prairie, savanna, woodland, and forest communities (Grimm 1984, Whitney and Steiger 1985, Leitner et al. 1991), with oak savannas and prairies occurring on sites exposed to frequent fire. Most oak savannas were plowed under for agricultural uses or succeeded to forest following reductions in fire frequency. High-quality savannas are now rare and mostly restricted to sites with infertile, sandy soils that were unattractive for agricultural uses, and where succession to woodland and forest communities was slow following reductions in fire frequency (Nuzzo 1986, WillWolf and Stearns 1999).

Prescribed fire is a management tool used to restore and maintain savannas and woodlands. Although it is well known that fire exerts strong influence on savanna and woodland stand dynamics and structure, the relationship between fire frequency and these ecosystem properties is still poorly understood in most of the savanna and woodland ecosystems of the world. Experimental tests are needed to determine the effects of different fire regimes on vegetation dynamics and to assess the utility of prescribed fire for the restoration and maintenance of remnant and degraded savannas and woodlands (McPherson 1997).

To better understand the relationship between fire frequency and stand structure, we studied the effects of a long-term prescribed burning experiment (1964-
1995) on stand structure and dynamics in upland oak savanna and woodland stands within the historic forest-prairie border in midwestern North America. Prescribed burning treatments were designed to vary fire frequency while controlling fire season and, to a lesser degree, fire intensity and pattern. Fire frequency treatments ranged from complete fire protection to nearannual burning (eight fires per decade), encompassing much of the range of reported presettlement fire frequencies along the forest-prairie border (Muir 1913, Stout 1944, Clark 1990, Guyette and Cutter 1991, Cutter and Guyette 1994).

To describe the cumulative effects (1964-1995) of prescribed burning frequency on stand structure, we compared stem density and species composition of overstory and understory trees of stands in each of the treatment units and in several stands with similar origins that were protected from fire. Fire effects were examined at different life history stages (seedling/ sprout, sapling, and mature tree) to better describe how fire influences stand structure. Stand basal area and diameter distributions were also calculated for overstory trees.

We also examined tree mortality rates and changes in stand structure over the most recent 11-yr period (1984-1995), using repeated tree survey measurements from permanent plots established in 1984. Our objectives were to (1) describe recent changes in the treatment units and update earlier reports from this study (White 1983, Tester 1989, Faber-Langendoen and Tester 1993), (2) investigate structural stability under different fire regimes, and (3) study the effects of fire frequency, species traits, and tree diameter on tree mortality rates.

\section{BACKGROUND}

\section{Study area}

The study area is part of the Cedar Creek Natural History Area (CCNHA), a 2300-ha reserve located on the Anoka Sand Plain in east-central Minnesota $\left(45^{\circ} 25^{\prime}\right.$ $\left.\mathrm{N}, 93^{\circ} 10^{\prime} \mathrm{W}\right)$. The climate is humid continental, with warm summers and cold winters. Mean annual temperature is $6^{\circ} \mathrm{C}$, with mean daily temperatures ranging from $22^{\circ} \mathrm{C}$ in July to $-11.5^{\circ} \mathrm{C}$ in January. Mean annual precipitation is $79 \mathrm{~cm}$, with $64 \%$ of this total occurring during the active growing season (May-September).

The terrain is relatively flat, with total relief of less than $10 \mathrm{~m}$. Soils are excessively drained, fine-to-medium sands of the Sartell (Typic Udipsamment) and Zimmerman (Alfic Udipsamment) series (Grigal et al. 1974). Both soils have low water-holding capacity and low fertility. The local water table is relatively shallow, lying within $7 \mathrm{~m}$ of the soil surface throughout the study area.

Upland areas of Cedar Creek currently support a mosaic of forest, savanna, and old fields. Floristically, these communities closely resemble the southern dry 
TABLE 1. Fire history of prescribed burning units at Cedar Creek Natural History Area, Minnesota, USA, including dates of burns (month/day, by year), total number of burns since 1964, and unit areas.

\begin{tabular}{|c|c|c|c|c|c|c|c|c|c|c|}
\hline \multirow{2}{*}{$\begin{array}{l}\text { Burn } \\
\text { year }\end{array}$} & \multicolumn{2}{|c|}{$\begin{array}{l}\text { Low-frequency } \\
\text { burn units }\end{array}$} & \multicolumn{8}{|c|}{ High-frequency burn units } \\
\hline & 111 & 113 & 107 & 108 & 201 & 105 & 101 & 106 & 103 & 104 \\
\hline 1964 & & & & & & & $4 / 16$ & & & \\
\hline 1965 & & & & & & $5 / 4$ & $4 / 28$ & & $5 / 4$ & $5 / 4$ \\
\hline 1966 & & & $8 / 30$ & & & $4 / 25$ & $4 / 13$ & $4 / 25$ & $4 / 25$ & $4 / 25$ \\
\hline 1967 & & & $9 / 6$ & $4 / 10$ & $4 / 27$ & $5 / 5$ & $4 / 27$ & $7 / 31$ & $4 / 14$ & $5 / 5$ \\
\hline 1968 & & $4 / 29$ & & $4 / 29$ & $4 / 26$ & & & & $4 / 26$ & $4 / 26$ \\
\hline 1969 & $5 / 14$ & & $4 / 23$ & & & & & $4 / 23$ & $5 / 12$ & $5 / 12$ \\
\hline 1970 & & & & & & & $5 / 4$ & $5 / 19$ & & $5 / 4$ \\
\hline 1971 & & & & $5 / 12$ & & $4 / 29$ & & & $4 / 21$ & $4 / 29$ \\
\hline 1972 & & & & $4 / 25$ & $5 / 8$ & $4 / 25$ & $5 / 8$ & $4 / 17$ & $5 / 18$ & $4 / 25$ \\
\hline 1973 & & & $5 / 16$ & & $5 / 26$ & $5 / 16$ & $4 / 26$ & $5 / 15$ & $5 / 16$ & $4 / 26$ \\
\hline 1974 & & & & & & & & & $4 / 16$ & $5 / 18$ \\
\hline 1975 & & & $5 / 12$ & $5 / 12$ & & & & $5 / 12$ & & $5 / 5$ \\
\hline 1976 & & $5 / 6$ & & & $4 / 26$ & & $4 / 26$ & $4 / 29$ & $4 / 26$ & $4 / 29$ \\
\hline 1977 & & & & & $4 / 25$ & $4 / 26$ & $4 / 25$ & & $4 / 25$ & $4 / 26$ \\
\hline 1978 & & & & $5 / 15$ & & $4 / 28$ & $5 / 1$ & $5 / 10$ & $5 / 1$ & $4 / 28$ \\
\hline 1979 & & & $5 / 16$ & $5 / 16$ & & $5 / 9$ & & $5 / 15$ & $5 / 9$ & $5 / 9$ \\
\hline 1980 & & & $5 / 14$ & & $4 / 17$ & & & & $4 / 17$ & $5 / 21$ \\
\hline 1981 & $5 / 18$ & & $5 / 20$ & & $5 / 6$ & & $5 / 12$ & $5 / 6$ & $5 / 12$ & $5 / 7$ \\
\hline 1982 & & & & $5 / 24$ & & & $4 / 3$ & $4 / 27$ & & $4 / 29$ \\
\hline 1983 & & $5 / 25$ & & $5 / 11$ & & $5 / 5$ & & & $5 / 5$ & $4 / 25$ \\
\hline 1984 & & & & & & $5 / 10$ & & $4 / 17$ & $5 / 10$ & \\
\hline 1985 & $5 / 5$ & & $5 / 7$ & & $5 / 7$ & $4 / 29$ & & $4 / 11$ & $4 / 19$ & \\
\hline 1986 & & & & & $5 / 7$ & & $5 / 7$ & & & \\
\hline 1987 & & & & & & & & $5 / 4$ & $5 / 5$ & \\
\hline 1988 & & & & $4 / 11$ & & & & $5 / 18$ & & $5 / 19$ \\
\hline 1989 & & & $4 / 25$ & & & $5 / 12$ & & & $4 / 25$ & $5 / 12$ \\
\hline 1990 & & & & & & $5 / 3$ & & $5 / 3$ & $5 / 3$ & $5 / 3$ \\
\hline 1991 & & & & & $5 / 14$ & & $5 / 14$ & $5 / 14$ & & $5 / 14$ \\
\hline 1992 & & & & $5 / 8$ & & & & & $5 / 8$ & \\
\hline 1993 & & & $5 / 5$ & & $5 / 10$ & & $5 / 10$ & $5 / 5$ & $5 / 5$ & $5 / 10$ \\
\hline 1994 & $4 / 20$ & $5 / 12$ & & $5 / 10$ & $4 / 21$ & $4 / 22$ & & $4 / 20$ & $5 / 5$ & $4 / 22$ \\
\hline 1995 & & & & & $5 / 2$ & & $5 / 2$ & & $5 / 4$ & $5 / 12$ \\
\hline No. burns & 4 & 4 & 11 & 12 & 14 & 15 & 16 & 20 & 25 & 26 \\
\hline Area (ha) & 12.1 & 11.3 & 2.8 & 27.5 & 2.4 & 16.2 & 13.4 & 8.1 & 10.9 & 18.2 \\
\hline
\end{tabular}

forest, oak barren, and dry-mesic prairie types, respectively, described in Wisconsin by Curtis (1959). Northern pin oak (Quercus ellipsoidalis) and bur oak (Quercus macrocarpa) are the dominant tree species. Important shrubs include American hazel (Corylus americana), smooth sumac (Rhus glabra), and chokecherry (Prunus virginiana). Big bluestem (Andropogon gerardii), little bluestem (Schizachyrium scoparius), Indiangrass (Sorghastrum nutans), Kentucky bluegrass (Poa pratensis), woodbine (Parthenocissus vitacea), hog peanut (Amphicarpa bracteata), poison ivy (Rhus radicans), and sedges (Carex pensylvanica and others) are common understory species. Taxonomy follows Gleason and Cronquist (1963).

\section{Burning program and experiment}

A prescribed burning program was initiated at CCNHA in 1964 to restore and maintain oak savanna and woodland vegetation and to test the effects of different prescribed burning treatments on vegetation structure (Irving 1970). An area of $\sim 210$ ha was divided into 14 burn units of 2.4-30 ha each, with burn unit boundaries determined largely by the availability of existing fire breaks, including roads, lakes, and wetlands. Each burn unit was randomly assigned to one of seven burn frequency treatments, ranging from annual burns to complete fire exclusion (Irving 1970). Burns were usually conducted in April or May (Table 1), after snow melt and before leaves appeared on the oaks. Most burns were ignited using a strip headfire technique (Irving 1970, Pyne et al. 1996).

During the period 1964-1995, 147 prescribed burns were conducted. Individual management units experienced 0-26 fires during that time (Table 1). Typical burning conditions included air temperatures of 15$25^{\circ} \mathrm{C}$, relative humidity of $25-45 \%$ and winds $<20 \mathrm{kph}$. Fire behavior varied with weather conditions and fuel loads, but fires were generally of low intensity, with mean flame lengths $<1 \mathrm{~m}$ (D. W. Peterson, personal observation).

\section{Methods \\ Data collection}

Permanent plots were established in the burn units, starting in 1984, to allow repeated sampling of tree, 
TABLE 2. Changes in tree density and stand basal area for all tree species pooled (stems $\geq$ $10 \mathrm{~cm} \mathrm{dbh)} \mathrm{from} 1979$ to 1995

\begin{tabular}{|c|c|c|c|c|c|c|c|c|c|c|c|}
\hline \multirow{2}{*}{$\begin{array}{l}\text { Burn } \\
\text { unit }\end{array}$} & \multirow{2}{*}{$\begin{array}{c}\text { No. } \\
\text { burns }\end{array}$} & \multirow[b]{2}{*}{ Plot } & \multirow[b]{2}{*}{ Soil $\dagger$} & \multicolumn{4}{|c|}{ Tree density (no. stems/ha) } & \multicolumn{4}{|c|}{ Basal area $\left(\mathrm{m}^{2} / \mathrm{ha}\right)$} \\
\hline & & & & 1979 & 1984 & 1990 & 1995 & 1979 & 1984 & 1990 & 1995 \\
\hline \multirow[t]{2}{*}{109} & 0 & 15 & $\mathrm{Zm}$ & 845 & 589 & 483 & 435 & 26.2 & 26.9 & 27.5 & 27.4 \\
\hline & 0 & 18 & $\mathrm{Sa}$ & & & 568 & 552 & & & 20.6 & 22.7 \\
\hline 209 & 0 & 9 & $\mathrm{Sa}$ & & 171 & 168 & 229 & & 17.1 & 12.3 & 13.7 \\
\hline 110 & 0 & 10 & $\mathrm{Sa}$ & & 173 & 211 & 261 & & 15.3 & 16.5 & 17.4 \\
\hline \multirow[t]{2}{*}{409} & 0 & 17 & $\mathrm{Sa}$ & & & 280 & 293 & & & 22.7 & 24.3 \\
\hline & 0 & 19 & $\mathrm{Sa}$ & & & 131 & 168 & & & 10.3 & 12.0 \\
\hline 120 & 0 & 20 & $\mathrm{Zm}$ & & & 357 & 371 & & & 27.4 & 28.2 \\
\hline 117 & 0 & 905 & $\mathrm{Sa}$ & & & 317 & 347 & & & 14.8 & 16.4 \\
\hline 111 & 4 & 11 & $\mathrm{Sa}$ & & 115 & 64 & 48 & & 11.8 & 6.9 & 5.4 \\
\hline 113 & 4 & 13 & $\mathrm{Sa}$ & & 99 & & 109 & & 9.9 & & 9.7 \\
\hline 107 & 11 & 7 & $\mathrm{Sa}$ & & 301 & 205 & 192 & & 13.4 & 11.7 & 11.9 \\
\hline 108 & 12 & 8 & $\mathrm{Sa}$ & 407 & 291 & 283 & 261 & 15.2 & 15.0 & 14.8 & 14.2 \\
\hline 201 & 14 & 16 & $\mathrm{Zm}$ & 200 & 221 & 147 & 104 & 16.6 & 15.7 & 12.1 & 9.9 \\
\hline 105 & 15 & 5 & $\mathrm{Sa}$ & 193 & 72 & 51 & 37 & 10.2 & 4.3 & 3.4 & 2.2 \\
\hline 101 & 16 & 1 & $\mathrm{Zm}$ & 433 & 197 & 144 & 99 & 22.0 & 14.7 & 10.1 & 6.8 \\
\hline 106 & 20 & 6 & $\mathrm{Sa}$ & 367 & & 240 & 219 & 12.4 & & 12.9 & 13.2 \\
\hline 103 & 25 & 3 & $\mathrm{Zm}$ & 436 & 405 & 312 & 203 & 15.9 & 14.1 & 12.2 & 9.2 \\
\hline \multirow[t]{2}{*}{104} & 26 & 4 & $\mathrm{Sa}$ & 174 & 163 & 83 & 69 & 10.4 & 13.8 & 8.4 & 6.5 \\
\hline & 26 & 24 & $\mathrm{Sa}$ & & & & 91 & & & & 5.4 \\
\hline
\end{tabular}

Notes: Density and basal area estimates for 1984-1995 are from permanent plot measurements. Values for 1979 are from random plot sampling in the same burn units (White 1981).

$\dagger$ Sartell (Sa) or Zimmerman (Zm) soil series.

shrub, and herbaceous community composition. Between 1984 and 1995, 19 plots were established in areas ranging from open bur oak savanna to closed oakmaple forest stands, and representing a fire frequency gradient from zero to 26 fires in $32 \mathrm{yr}$ (Table 2). Twelve of these plots (nine burned, three unburned) were first sampled in 1984 and provided an 11-yr record of changes in stand structure. Most burn units contained only one plot. One burn unit (number 104) contained two plots, representing areas with different original stand structure and species composition.

The sampling layout at each permanent plot consisted of four parallel 50-m transects placed $25 \mathrm{~m}$ apart, outlining an area of 0.375 ha $(50 \times 75 \mathrm{~m})$. Quadrat sampling points were placed at $10-\mathrm{m}$ intervals along each transect for a total of 24 sample points per plot. In 1995, temporary transects were placed midway between each pair of permanent transects to provide an additional 18 sample points on most plots.

Tree surveys.-Tree sampling included all trees within the 0.375-ha plot area. Tree surveys in 1984, 1990, and 1995 recorded species, status (alive, dead, snag, fallen), and diameter at breast height (dbh) for each stem within the plot boundaries. Surveys in 1984 and 1995 used a minimum size cutoff of $5 \mathrm{~cm}$ dbh for inclusion in the survey, whereas the 1990 survey used a minimum size of $10 \mathrm{~cm} \mathrm{dbh}$. For consistency, we limited our analysis to stems $\geq 10 \mathrm{~cm} \mathrm{dbh}$. Many plots contained multistemmed individuals, mostly northern pin oaks, which apparently originated from sprouts. These stems were recorded individually on the tree surveys.

Seedling and sapling surveys.-Seedling/sprout and sapling stem densities were based on stem counts from circular quadrats placed at each quadrat sampling point ( 24 or 42 per plot). Seedlings/sprouts (trees $<1.5 \mathrm{~m}$ tall) were tallied by species within a $1 \mathrm{~m}$ radius quadrat centered on each quadrat sample point. Species and $\mathrm{dbh}$ were recorded for all saplings (trees $\geq 1.5 \mathrm{~m}$ tall and $<5 \mathrm{~cm}$ dbh) within a $2 \mathrm{~m}$ radius quadrat centered on each quadrat sample point.

Most seedling and sapling surveys were conducted during the 1995 growing season. Sapling surveys in burn units 111 and 113 (plots 11 and 13) were conducted in 1996, however. Both plots are on a lowfrequency burning schedule and were burned in 1994. Sapling counts in 1995 were very low (and seedling counts very high) because most of the resprouting stems were only $1 \mathrm{yr}$ old and were still in the seedling size class. Sapling counts in 1996 were considered better estimates of typical sapling densities throughout the 8-9 yr fire return interval, because many of the resprouting stems had reached the minimum height of $1.5 \mathrm{~m}$. This was not an issue in more frequently burned units because fire intervals are too short and sprout growth rates are too slow to allow sprout stems to reach $1.5 \mathrm{~m}$ in height.

\section{Data analysis}

Tree stem density and stand basal area were calculated for each plot, based on tree survey data from 1984, 1990, and 1995. Tree density and basal area were also calculated from a 1979 survey of eight burn units (White 1981) that sampled trees in randomly placed plots $\left(100 \mathrm{~m}^{2}\right.$ each, $\left.1 \mathrm{plot} / \mathrm{ha}\right)$ throughout the burn units. Tree stem densities were partitioned into diameter classes and by species to examine fire frequency effects on tree diameter distributions and species composition. 
Burn units were grouped into high-frequency (11-26 burns), low-frequency (four burns), and unburned (zero burns) categories, and means were calculated for each size class and species. Sapling densities were also summarized by species and burn frequency group.

Effects of prescribed burning frequency and soil series on seedling densities were tested using stepwise linear regression procedures for each of the five major tree species. Seedling densities were transformed prior to regression analysis using a common logarithm function, $\log _{10}(x+10)$ where $x$ is density in number of individuals per hectare. Candidate predictor variables included (1) the number of fires from 1964 to 1995; (2) a Boolean variable for soil series effects (Sartell, 1; Zimmerman, 0); (3) a fire-soil term to test for possible interactions between (1) and (2); and (4) a Boolean fire treatment variable ( 1 , burned; 0 , no fire).

Annual proportional changes in tree density and basal area were determined using a mean relative growth rate calculation,

$$
\mathrm{RGR}=\left[\log _{e}\left(x_{2}\right)-\log _{e}\left(x_{1}\right)\right] /\left(t_{2}-t_{1}\right)
$$

where RGR is mean relative growth rate, $x_{1}$ and $x_{2}$ are the density or basal area at times $t_{1}$ and $t_{2}$, respectively, and time is measured in years. Mean annual percentage change is then calculated as $\left(e^{\mathrm{RGR}}-1\right) \times 100$. Rates of change on the original 12 plots were determined for the period 1984-1995. Linear regression was used to test for significant effects of fire frequency on rates of change in basal area and density.

To examine tree mortality rates for the interval 1984-1995, we matched trees in 1995 with their measurements from earlier surveys (Peterson 1998). Trees that were alive in 1984 were coded as alive or dead in 1995. Logistic regression procedures were then used to estimate tree mortality rates for northern pin oak and bur oak as functions of fire frequency and tree diameter in 1984 (PROC LOGISTIC, SAS/STAT software version 6.10, SAS Institute 1989). Linear and quadratic terms for the number of fires during 1985-1995 (fire frequency) and 1984 tree diameters were included as candidate predictor variables. A log-likelihood statistic was used to test the null hypothesis of no fire frequency or tree diameter effects on the probability of stem mortality. Wald statistics were used to test statistical significance of individual linear predictors. Predictor variables were considered significant if $P<0.05$ for the pin oak model. A cutoff of $P<0.10$ was used for the bur oak model because of the smaller sample size. Pearson residuals were used to further evaluate model fit.

\section{RESULTS}

\section{Fire effects on seedling/sprout densities}

Seedling/sprout densities declined exponentially with increasing fire frequency for four of the five major tree species (Fig. 1). Red maple (Acer rubrum) was the most sensitive to burning. Red maple seedlings were present on all but one of the unburned plots, but only one of the burned plots. Black cherry (Prunus serotina) and serviceberry (Amelanchier sp.) seedlings were present on most plots, but their densities declined significantly with increasing fire frequency.

Oak seedling densities were less sensitive to fire frequency (Fig. 1). Northern pin oak (Quercus ellipsoidalis) had a statistically significant decline in seedling density with increasing fire frequency, but even frequently burned plots (10-26 fires) averaged $>6500$ seedling or sprout stems per hectare, so the decline is probably not ecologically significant. Bur oak (Quercus macrocarpa) seedling densities did not change significantly along the fire frequency gradient, but did differ between soil series (Fig. 1); there were significantly fewer bur oak seedlings on Zimmerman than on Sartell soils. Many of the oak seedling/sprouts in the frequently burned units are "grubs," well established individuals that are repeatedly top-killed by fires but resprout from belowground buds, often producing a multistemmed morphology.

\section{Fire effects on sapling densities}

Sapling densities were highest in the low-frequency burn units, intermediate in the unburned units, and nearly zero in the frequently burned units (Table 3 ). In 1994, fires burning through dense thickets top-killed most saplings in the low-frequency burn units, but rapid growth of root sprouts resulted in an average density of almost 10000 saplings/ha in these units by 1996 . Most of these saplings were pin oaks, with some black cherries and bur oaks. In general, it takes at least three growing seasons for oak and cherry sprouts at CCNHA to reach the minimum sapling height of $1.5 \mathrm{~m}$, so units burned on a cycle of less than three years rarely have saplings by this definition. Sapling species composition on unburned plots was more varied. Areas with large openings or treefall gaps contained most of the oak saplings. Serviceberry and black cherry saplings were most abundant in smaller gaps and oak woodland understories. Red maple saplings were uncommon except in one older forest stand (plot 20).

\section{Fire effects on overstory species composition, density, and basal area}

Pin oak was the dominant overstory species in closed woodland and forest stands, accounting for an average of $88 \%$ of stand basal area and $75 \%$ of stems $\geq 10 \mathrm{~cm}$ dbh in the unburned plots (Table 4). Pin oak was also dominant in many of the open savanna areas, but at reduced density and basal area. Bur oak was present in most stands and codominant in many of the open savanna stands. Non-oak species were rare in the frequently burned units. Paper birch (Betula papyrifera), black cherry, and serviceberry occurred at low densities on the low-frequency burn plots. Black cherry, red maple, and serviceberry were common on unburned 

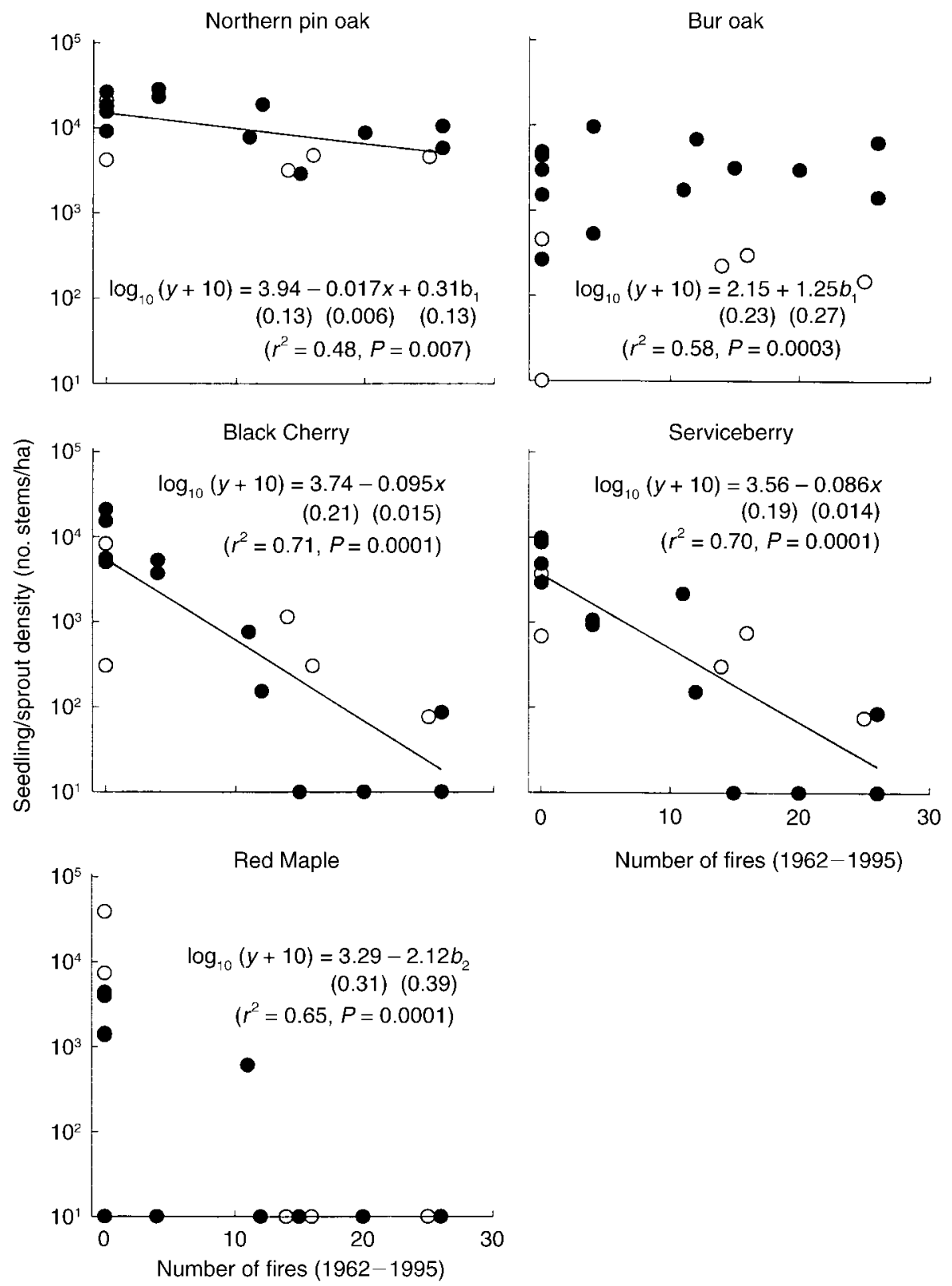

FIG. 1. Effects of fire frequency and soil type on seedling densities, by species. Soil type for each plot is indicated by open (Zimmerman) and solid (Sartell) symbols. Predictor variables in the regression equations include the number of fires $(x)$, a boolean soils variable $\left(b_{1}\right)\left(1\right.$, Sartell; 0 , Zimmerman), and a boolean fire variable $\left(b_{2}\right)$ ( 1 , burned; 0 , no fires). Interactions were not significant. Numbers in parentheses below the regression equation are standard errors for the regression parameters.

plots, where they have been slowly increasing in density and basal area since 1984 (data not shown).

Tree density and basal area were lower in burned than in unburned units (Table 4). Stem density in 1995 ranged from 37 to 261 stems/ha in burned units and from 168 to 552 stems/ha in unburned units (Table 2) for stems $\geq 10 \mathrm{~cm} \mathrm{dbh}$. Stand basal area varied between 2.2 and $14.2 \mathrm{~m}^{2} /$ ha in burned units and between 13.7 and $28.2 \mathrm{~m}^{2} / \mathrm{ha}$ in unburned units. Although there is a clear difference between burned and unburned plots, linear regression tests failed to reject a null hypothesis of no fire frequency effect on stem density $(F=0.37$, $P=0.56)$ or on basal area $(F=0.03, P=0.87)$ when unburned plots were excluded from the analysis.

Rates of decline in tree density and basal area during the period 1984-1995 were correlated with fire frequency (Fig. 2). Rates of change in stand density varied from no net change on unburned plots to about an $8 \%$ annual decline on frequently burned plots. Similarly, changes in basal area ranged from a $1 \%$ annual decline on unburned plots to about a $7 \%$ annual decline on frequently burned plots. The number of fires was a 
TABLE 3. Mean stem density (no. stems/ha) of saplings ( $\geq$ $1.5 \mathrm{~m}$ height and $<5 \mathrm{~cm}$ dbh), by species.

\begin{tabular}{lccc}
\hline \hline & \multicolumn{3}{c}{ Mean stem density (no. stems/ha) } \\
\cline { 2 - 4 } \multicolumn{1}{c}{ Species } & No fire & $\begin{array}{c}\text { Low } \\
\text { frequency } \\
\text { (4 fires) }\end{array}$ & $\begin{array}{c}\text { High } \\
\text { frequency } \\
\text { (11-26 } \\
\text { fires) }\end{array}$ \\
\hline Red maple & 62 & 0 & 0 \\
Serviceberry & 255 & 33 & 0 \\
Black cherry & 124 & 1840 & 0 \\
Northern pin oak & 319 & 7709 & 19 \\
Bun oak & 89 & 215 & 2 \\
Other & 49 & 0 & 0 \\
\hline
\end{tabular}

Note: Densities are from 1995/1996 surveys and are summarized by burn frequency class.

significant predictor in regression analyses of these data, with $r^{2}$ values of 0.55 and 0.37 for density and basal area, respectively.

\section{Fire effects on stand size structure and tree mortality rates}

Frequently burned ( $\geq 11$ fires) and unburned units had significantly different mean tree size distributions after 32 years of prescribed burning (KolmogorovSmirnoff test, $P<0.001)$. Trees in frequently burned units had a unimodal size distribution, with highest stem densities in the $20-30 \mathrm{~cm}$ size class (Fig. 3). Stem densities in the unburned and infrequently burned (four fires) units were highest in the smallest size class (5$10 \mathrm{~cm}$ ) and declined with increasing size. Pin oaks were abundant in all size classes in unburned units, but were virtually absent from the $5-10 \mathrm{~cm}$ dbh size class in frequently burned units. The $5-10 \mathrm{~cm}$ size class in frequently burned units was dominated by small bur oaks that were saplings or small trees when the prescribed burning program began.

Comparisons of size distributions in 1984 and 1995 show that changes occurred in all three treatment groups (Fig. 4). For frequently burned units, the mode of the distribution curve shifted from the $10-20 \mathrm{~cm}$ class to the $20-30 \mathrm{~cm}$ class, and density declined in all dbh classes. Low-frequency burn units had reductions in tree density in the larger size classes, along with ingrowth of new individuals to the $5-10 \mathrm{~cm}$ size class. Changes in tree size distributions within stands protected from fire varied with stand age and structure, with the net effect being an increase in tree density in the $5-10 \mathrm{~cm}$ dbh size class (Fig. 4).

Mortality rates for pin oak (27\%) and bur oak (18\%) were not significantly different on unburned plots for the period 1984-1995 (Table 5). Northern pin oak mortality rates almost doubled with burning in comparison to unburned plots, however, whereas bur oak rates were reduced by half. As a result, pin oak mortality was six times higher than that of bur oak on burned plots. These clear species differences in mortality response to fire led us to test the two oak species independently for
TABle 4. Mean tree basal area and stem density in 1995, by species, for trees ( $\geq \mathrm{cm} \mathrm{dbh})$ in the no-fire, low-frequency, and high-frequency burn treatment classes.

\begin{tabular}{|c|c|c|c|c|c|c|}
\hline \multirow[b]{2}{*}{ Species } & \multicolumn{3}{|c|}{ Basal area $\left(\mathrm{m}^{2} / \mathrm{ha}\right)$} & \multicolumn{3}{|c|}{$\begin{array}{c}\text { Density } \\
\text { (no. stems/ha) }\end{array}$} \\
\hline & $\begin{array}{l}\text { No } \\
\text { fire }\end{array}$ & $\begin{array}{l}\text { Low } \\
\text { freq. }\end{array}$ & $\begin{array}{l}\text { High } \\
\text { freq. }\end{array}$ & $\begin{array}{l}\text { No } \\
\text { fire }\end{array}$ & $\begin{array}{l}\text { Low } \\
\text { freq. }\end{array}$ & $\begin{array}{l}\text { High } \\
\text { freq. }\end{array}$ \\
\hline Northern pin oak & 18.23 & 5.62 & 6.60 & 262 & 45 & 93 \\
\hline Bur oak & 1.10 & 1.87 & 2.10 & 33 & 27 & 46 \\
\hline Other & 0.91 & 0.07 & 0.11 & 36 & 7 & 3 \\
\hline
\end{tabular}

effects of tree size and fire frequency on the probability of stem mortality. Mortality rates for non-oak species were not analyzed because of small sample sizes.

Pin oak mortality probabilities varied nonlinearly with both burn frequency and tree diameter (Table 6). Algebraic manipulation of the logistic regression model produced the equation

$$
\begin{aligned}
& \log _{e}(\pi(F, D) /(1-\pi(F, D))) \\
& \quad=0.056-0.041(F-5.68)^{2}+1.24(D-3.46)^{2}
\end{aligned}
$$
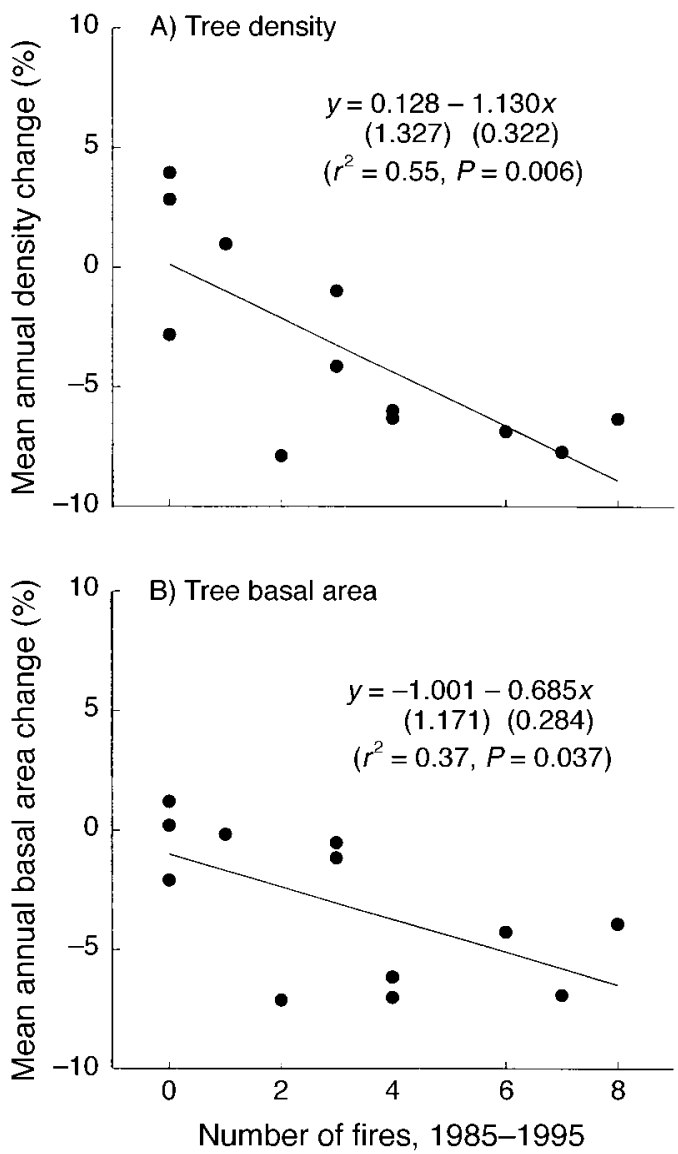

FIG. 2. Mean annual percentage change in (A) tree stem density and (B) basal area (stems $\geq 10 \mathrm{~cm}$ dbh) from 1984 to 1995 for individual plots under different prescribed burning frequencies. Numbers in parentheses below the regression equation are standard errors for the regression parameters. 


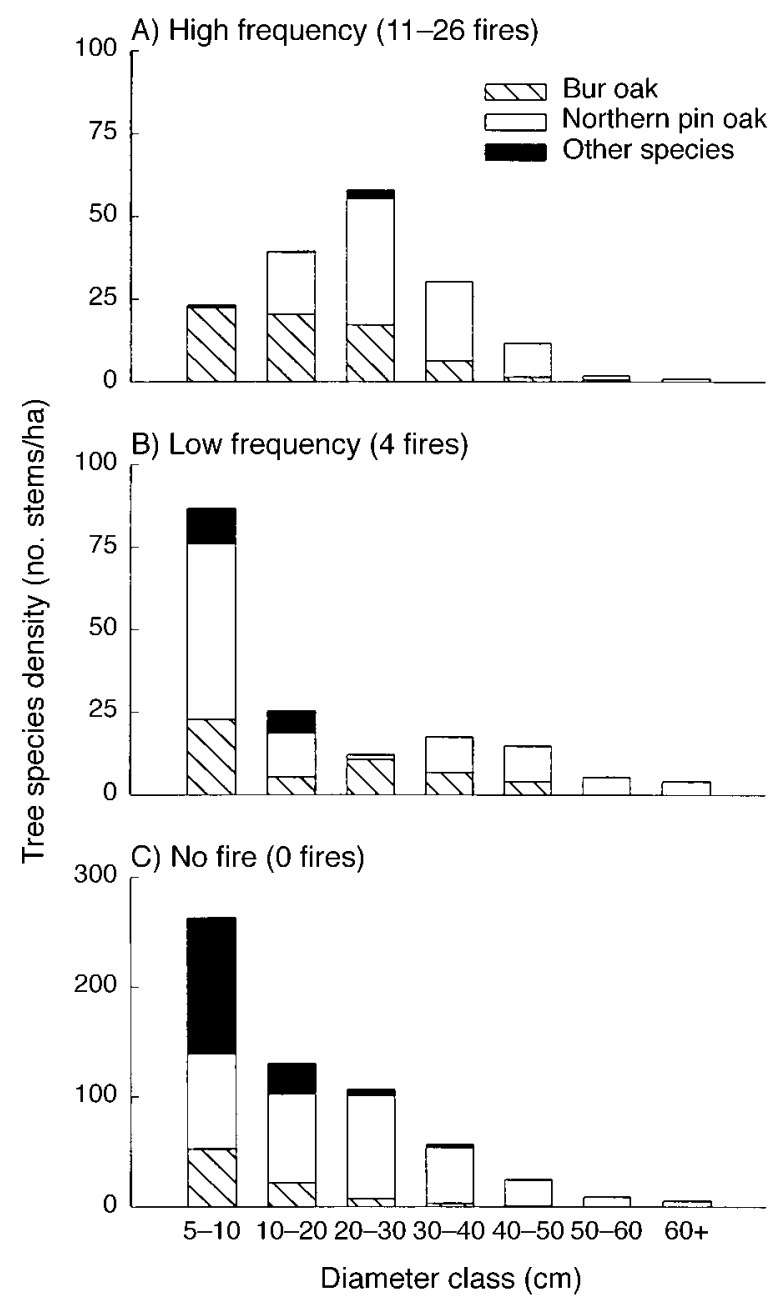

FIG. 3. Species composition and tree size structure in 1995 for stands in the high-frequency, low-frequency, and unburned treatment groups. Bars represent mean stem density, by species, within each diameter class.

where $F$ is the number of fires between the 1984 and 1995 surveys, $D$ is the natural (Napierian) logarithm of the tree diameter at breast height, $\pi(F, D)$ is the probability of mortality for a given fire frequency and tree diameter, and the left side of the equation is the log-transformed odds ratio. Partial differentiation of this equation with respect to fire frequency yielded a value of about five fires per decade (5.68 fires/11 yr) as the fire frequency with the highest expected rate (odds) of mortality. Differentiating with respect to tree diameter yielded a value of $32 \mathrm{~cm}\left(e^{3.46} \mathrm{~cm}\right)$ as the tree diameter (at the start of the period) with the lowest mortality rate. Expected rates of mortality gradually increased with increasing fire frequency from zero to five fires per decade, although the probabilities showed only minor differences between four and seven fires per decade. Probability of mortality decreased rapidly between 10 and $25 \mathrm{~cm} \mathrm{dbh}$, and then increased gradually beyond $32 \mathrm{~cm}$ (Fig. 5).
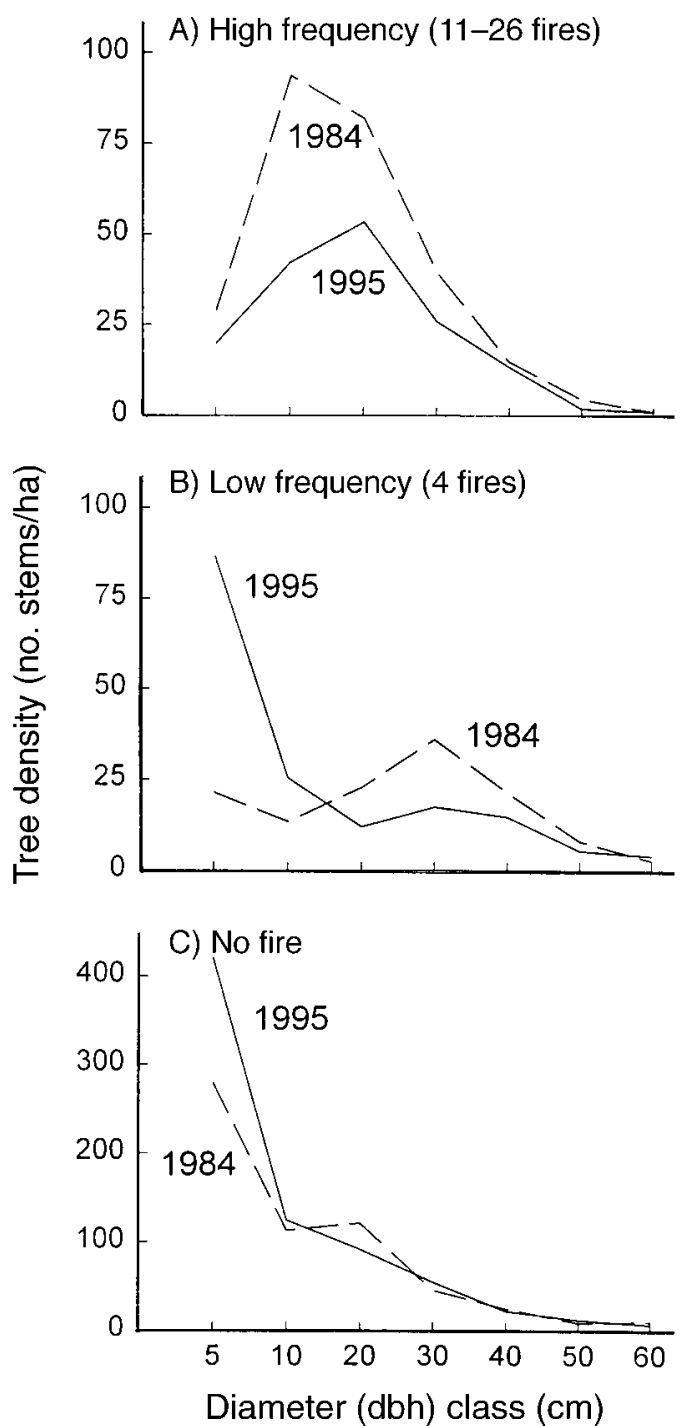

FIG. 4. Tree size structures in 1984 and 1995 for stands in the high-frequency, low-frequency, and unburned treatment groups. Lines show mean stem density (all species combined) within each diameter class. Horizontal axis labels display the minimum diameter for each size class.

TABLE 5. Tree mortality rates for northern pin oak and bur oak in burned and unburned stands during the period 19841995.

\begin{tabular}{lcc}
\hline \hline $\begin{array}{l}\text { Treatment, } \\
\text { by species }\end{array}$ & No. trees & Mortality rate $(\%)$ \\
\hline Bur oak & & \\
Unburned & 40 & $17.5^{\mathrm{a}, \mathrm{b}}$ \\
Burned & 120 & $8.3^{\mathrm{a}}$ \\
Northern pin oak & & \\
Unburned & 293 & $26.6^{\mathrm{b}}$ \\
Burned & 560 & $50.0^{\mathrm{c}}$ \\
\hline
\end{tabular}

Note: Species-treatment combinations with same letters are not significantly different $(P>0.05)$, based on tests of conditional independence. 
TABLE 6. Parameter estimates for tree mortality models.

\begin{tabular}{|c|c|c|c|c|c|c|c|c|}
\hline \multirow[b]{2}{*}{ Variable } & \multicolumn{4}{|c|}{ Northern pin oak } & \multicolumn{4}{|c|}{ Bur oak } \\
\hline & Estimate & $1 \mathrm{SE}$ & Wald $\chi^{2}$ & $P$ & Estimate & $1 \mathrm{SE}$ & Wald $\chi^{2}$ & $P$ \\
\hline Intercept & 13.54 & 3.72 & 13.28 & 0.001 & -1.54 & 0.37 & 17.59 & 0.001 \\
\hline Burns & 0.47 & 0.09 & 27.96 & 0.001 & -0.30 & 0.16 & 3.54 & 0.060 \\
\hline Burns² & -0.04 & 0.01 & 14.25 & 0.001 & & & & \\
\hline $\ln (\mathrm{dbh})$ & -8.62 & 2.32 & 13.82 & 0.001 & & & & \\
\hline $\ln (\mathrm{dbh})^{2}$ & 1.24 & 0.36 & 12.20 & 0.001 & & & & \\
\hline
\end{tabular}

Bur oak mortality was best modeled as a monotonically decreasing function of the number of burns during the period 1984-1995 (Table 6, Fig. 5). Although the chi-square test on the burn frequency parameter was only weakly significant $(P=0.06)$, residual analysis showed that this model fit the data well across the range of fire frequencies. There was no evidence for a size effect on bur oak mortality for individuals $\geq 10$

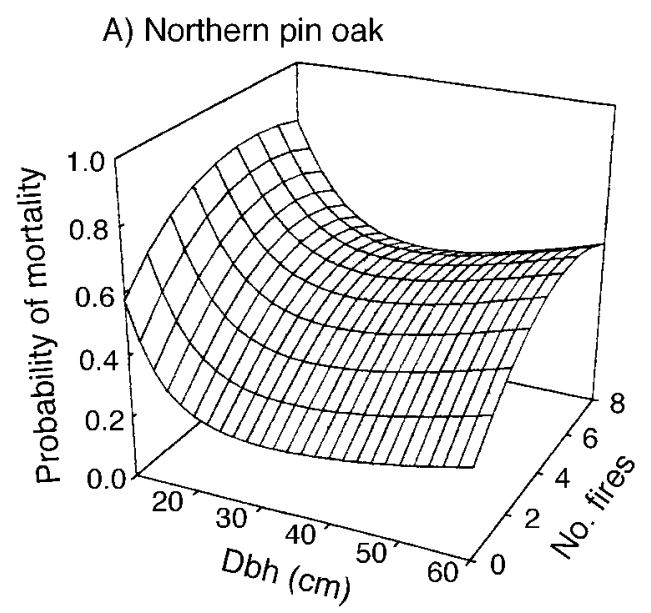

B) Bur oak

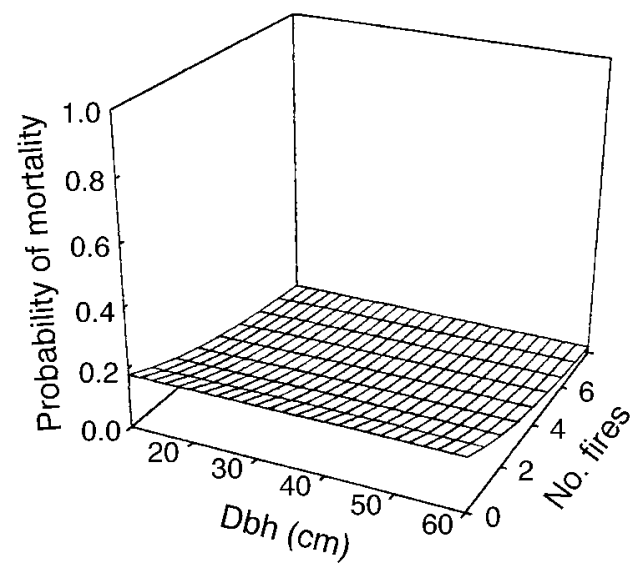

FIG. 5. Probability of mortality of individual oak trees over an 11-yr period (1985-1995) as a function of tree diameter and the number of fires during that period. Separate response surfaces are presented for (A) bur oak and (B) northern pin oak. $\mathrm{cm}$ dbh. Field observations suggest, however, that individuals in the $5-10 \mathrm{~cm}$ dbh size class have experienced higher mortality rates during this period in both unburned and burned stands.

\section{DISCUSSION}

The fire frequency treatments produced important differences in stand structure in upland oak savannas and woodlands after $32 \mathrm{yr}$ of prescribed burning. Stands receiving the high-frequency fire treatments (11 or more fires in $32 \mathrm{yr}$ ) featured suppressed bur oak (Quercus macrocarpa) and northern pin oak (Q. ellipsoidalis) seedling/sprouts, no sapling layer, no canopy ingrowth, low overstory tree density and basal area, and continued mortality of overstory northern pin oaks. Stands receiving the low-frequency fire treatment (four fires in $32 \mathrm{yr}$ ) featured bur oak, northern pin oak, black cherry (Prunus serotina), and serviceberry (Amelanchier sp.) in often dense sapling thickets, some ingrowth, and continued mortality of overstory oaks (see Plate 1). Stands protected from fire were dominated by northern pin oaks in the overstory, with increasing densities of black cherry, serviceberry, and red maple (Acer rubrum) in the seedling and sapling layers (see Plate 1). These structural differences among treatments in 1995 reflect a combination of stand history and structure prior to the burning program, structural changes produced by fires prior to the establishment of the longterm monitoring program, and recent changes in structure.

Although pretreatment stand structures were not measured, stand age structures (from tree-ring counts) and a series of aerial photos (1938-1995) provide useful information about stand histories and structural differences prior to the start of the burning program. The burn units contain three basic stand types, including (1) bur oak savanna with widely spaced bur oaks up to $250 \mathrm{yr}$ old and some younger northern pin oaks; (2) pin oak savanna/woodland with even-aged cohorts of northern pin oaks (1880-1900) and some older bur oaks; and (3) pin oak woodland/forest with relatively dense, even-aged stands of northern pin oaks that regenerated following a major disturbance (fire and/or logging) in the mid-1930s. Under fire exclusion from 1938 to 1964 , total canopy cover increased in all three stand types through tree crown expansion and ingrowth 
a

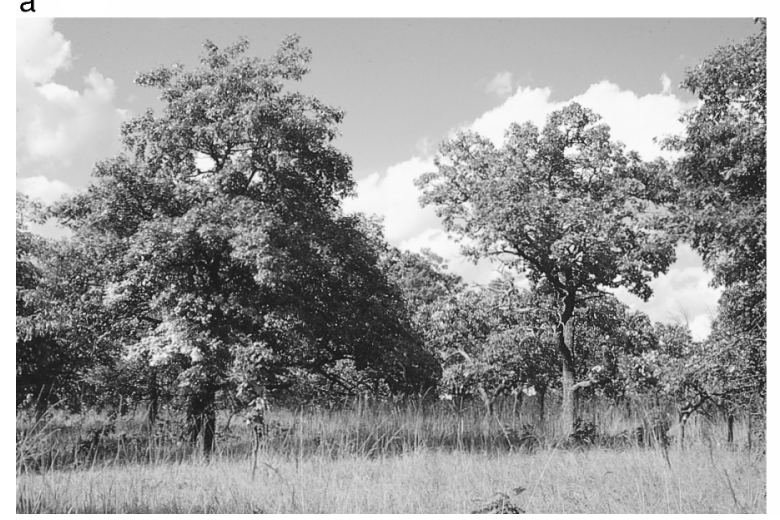

b

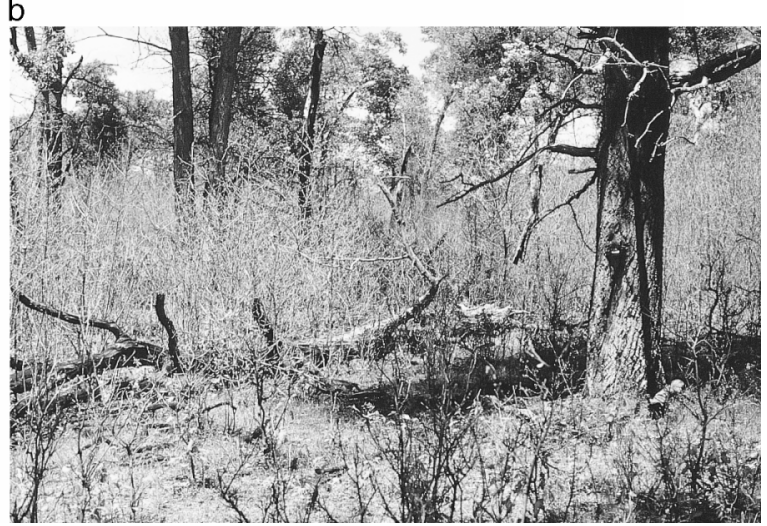

Plate 1. (a) Large, fire-resistant northern pin oaks (left) and bur oaks (right) persist in an open savanna with a highfrequency prescribed fire regime. (b) Oak seedlings and saplings resprout following a fire in an oak woodland with a lowfrequency prescribed fire regime. (Photos by David W. Peterson.)

of new trees, especially northern pin oaks (Faber-Langendoen and Davis 1995).

The first fires (1964-1966) in burn units 101-105 top-killed mostly small trees, many of which resprouted and persisted as suppressed, multistemmed sprouts (Sando 1967). Between 1968 and 1981, subsequent fires continued to kill the smallest trees (Irving and Aksamit 1983). In 1979, a study of a pair of burn units with a common stand history found that overstory density and basal area were significantly lower in the annually burned unit (burn unit 103) than in the unburned unit (unit 109), but that fires were having little effect on stems $>25 \mathrm{~cm} \mathrm{dbh}$.

We found that during the third decade of treatments, overstory density and basal area declined further in frequently burned units as a result of continued tree mortality and a complete lack of ingrowth. Tree mortality rates in frequently burned stands were highest for northern pin oaks in the smallest size classes, contributing to an increase in mean tree diameter and decreased dominance of northern pin oak in these stands. Structural changes in unburned units varied by stand type: the younger woodland/forest stands underwent self-thinning, whereas mortality of dominant northern pin oaks in former pin oak savanna/woodland stands created large gaps and allowed ingrowth of new trees.

\section{Fire frequency and species life history traits}

Several plant life history traits, or "vital attributes" (Noble and Slatyer 1980), are known to influence species responses to fire, and may be important for predicting long-term plant community responses to different fire regimes. These vital attributes include sprouting ability, bark thickness, shade tolerance, seed production and dispersal, and the time required for individuals to reach critical life history stages (Noble and Slatyer 1980). Rowe (1983) proposed a system, based on these vital attributes and the resulting species responses to fire, that allows species to be placed into one or more of five groups: resisters, endurers, avoiders, invaders, and evaders. The tree species in this study fall into the first three groups, which will be discussed in more detail.

Resisters.-Resisters are shade-intolerant species that survive low-severity fires with little or no damage (Rowe 1983). They usually have thick, insulating bark that protects stems from the heat of a fire and may also feature a long life-span and wood that resists decay after being exposed by fire scarring. Ponderosa pine (Pinus ponderosa), longleaf pine ( $P$. palustris), and bur oak are examples of resister species that are important in North American savannas and woodlands (Agee 1993, McPherson 1997, Anderson et al. 1999). By persisting in a mature reproductive stage, resisters maintain the potential for population growth whenever spatial or temporal variability in fire frequency and severity allows new individuals to become established and develop fire resistance (Cooper 1960).

Bur oak, a species within the white oak group (subgenus Leucobalanus), was clearly shown to be a resister species. Fire rarely killed mature bur oaks, even those in the smaller size classes; most bur oak mortality appeared to be caused by treefall damage in burned stands and by shading in unburned stands. As saplings, bur oaks develop a thick layer of corky bark that protects cambial tissues from the heat of periodic grass fires. Bark thickness continues to increase with increasing diameter at a very high rate compared to most other central hardwood species (Hengst and Dawson 1994). Mature bur oaks are therefore highly fire resistant and are rarely injured or killed by low-intensity prescribed fires.

Northern pin oaks, in the red oak group (subgenus Erythrobalanus), are slower to develop fire resistance, but can be considered resisters once they attain sufficient size. Northern pin oaks have thin bark as saplings and small trees $(<10 \mathrm{~cm} \mathrm{dbh})$ and are easily top-killed by fires of low to moderate intensity. Larger stems $(>25$ 
$\mathrm{cm}$ dbh) typically have thick bark and can avoid being top-killed by an individual fire, but may be scarred at the base if fuel or weather conditions produce local fire behavior of unusual intensity or duration. Scarred trees are less resistant to injury from future fires and more vulnerable to fungal infections, heartrot, and windthrow. Once killed, larger stems rarely resprout, perhaps because the root systems have decayed.

The nonlinear relationship between tree diameter and northern pin oak mortality rates probably reflects variations in bark thickness and age limitations. Bark thickness and fire resistance generally increase with tree diameter, reducing the probability of damage or death from fire. Northern pin oaks at Cedar Creek appear to have a relatively short life-span, however, and many of the largest trees (100-120 yr old) are decaying, probably explaining the higher mortality rates that we found for very large northern pin oaks in both burned and unburned stands. Mortality rates increased with fire frequency, probably because more frequent burning provided more opportunities for stem damage to occur. At very high burn frequencies, however, low fuel accumulation may reduce mean fire intensity and reduce the potential for stem damage from any single fire.

These differing mortality responses to fire frequency between two oak species, bur oak and northern pin oak, may be typical of differences between the two oak subgenera, the white oak and the red oak groups. In a study of long-term fire effects in oak-hickory forest, survival rates for $Q$. stellata (white oak group) were insensitive to burning except in the smallest size classes (Huddle and Pallardy 1996). In contrast, survival rates for red oak group species declined with annual and periodic burning and increased monotonically with pretreatment diameter.

Endurers.-Endurers are plants that are able to resprout after aboveground parts are damaged or killed by fire (Rowe 1983). This ability to resprout allows species to maintain existing populations on a site through a fire event. If nearly $100 \%$ of individuals resprout following fire, populations may be able to persist for long periods under a high-frequency (and high-severity) fire regime that exposes plants to repeated damage and prevents plants from reaching the reproductive stage. A long fire interval can release these suppressed individuals, produce rapid structural changes in the ecosystem (Stout 1944, Bowles and McBride 1998), and allow population growth through sexual reproduction and establishment of new individuals.

Endurer species that are important in savanna and woodland ecosystems include oaks (Quercus spp.), aspen (Populus tremuloides), Pacific madrone (Arbutus menziesii), and many shrub species (Rowe 1983, Agee 1993). Endurers are the dominant species in oak savannas and aspen parklands, and may be present as codominant trees or understory shrubs in many pine (Pinus spp.) savannas and woodlands.

The changes that we observed in seedling densities for each species across the fire frequency gradient can be attributed, at least in part, to differences in resprouting rates. Both oak species in this study had resprouting rates near $100 \%$ for individuals with wellestablished root systems (Peterson 1998), so both species can be called endurers. Muir (1913) stated that oak "grubs" in Wisconsin prairies and savannas could be up to $100 \mathrm{yr}$ old, despite being regularly top-killed by nearly annual fires, indicating the potential for long persistence of some endurer species once they are well established.

Low seedling densities for black cherry, serviceberry, and red maple in frequently burned stands are probably the combined result of lower resprouting rates, lack of local overstory seed trees, and increased competition from grasses and other understory herbaceous species in the more open stands. Red maple seedling densities declined by $75 \%$ following a single prescribed burn in an oak forest in Wisconsin, compared to a $35 \%$ reduction in black cherry and no change in northern pin oak (Reich et al. 1990; see also Huddle and Pallardy 1999). Repeated burning could lead to rapid reductions in these populations. Therefore, although they have the ability to resprout following fire, these species cannot be considered endurers under the range of prescribed fire regimes included in this study.

Avoiders.-Avoiders are shade-tolerant and fire-sensitive species that slowly reinvade a site following disturbance (Rowe 1983, Agee 1993). They require a long fire-free period to become established, and juveniles are easily killed by fire, although mature trees may develop some fire resistance. By increasing shading and altering fuel characteristics, avoiders may alter future fire behavior, especially fire intensity.

Red maple is clearly an avoider species, and black cherry and serviceberry are probably best described as avoiders, despite their ability to resprout following fire. None of these species was found in the overstory of burned stands; any trees present at the beginning of the prescribed burning program were probably small and were quickly killed. Fire protection has allowed these species to increase in importance over time as shading from expanding tree and shrub canopies reduces competition from the understory herbaceous layer. This process is probably similar to what happened throughout much of Minnesota and Wisconsin between 70 and 140 years ago (Muir 1913, Curtis 1959).

After canopy closure, future successional changes are largely driven by gap replacement processes, which favor red maple on sandy soils (Nowacki et al. 1990). The stand containing plot 20 (fire protection treatment) was first surveyed in 1947, when it was a young, dense pin oak stand (35-40 yr old and 925 stems/ha) with some white oak (Quercus alba) and bur oak in the tree layer (Chu 1948). By 1995, red maples accounted for $25 \%$ of the stems $\geq 10 \mathrm{~cm}$ and $74 \%$ of individuals in the 5-10 cm size class. We expect red maple to continue to increase in importance in stands protected from fire, 
consistent with the idea that oak forests are a transitional community in this region in the absence of fire or some other stand-replacing disturbance (Cottam 1949, Crow 1988, Abrams 1992).

\section{Implications for savanna restoration and management}

Prescribed burning is commonly used for savanna restoration on sites that once supported savanna vegetation, but have since grown into woodland or forest. Restoration objectives in such cases may include reducing overstory tree density and basal area to levels reported for historical savannas, selecting for historically important savanna tree species, eliminating or suppressing understory shrubs and trees (including exotic invaders), and facilitating development of a continuous herbaceous layer dominated by grasses. After these objectives have been met, prescribed burning regimes may be adjusted to maintain savanna structure and composition.

Our results agree with conclusions of previous studies that a burning schedule of annual to biennial fires is needed to produce the most rapid reductions in tree canopy density (Faber-Langendoen and Davis 1995). There is little difference in tree mortality, however, for burning frequencies with mean return intervals of one to three years. Within this range, the actual fire frequency applied should therefore be chosen to suit other objectives, such as control of shrub dominance, ease and safety of burning, or minimization of management costs.

One problem with using prescribed burning alone to reduce overstory density and basal area in stands long protected from fire is that even avoider species can develop thick bark and fire resistance when mature (Harmon 1984). These unwanted species may slow or prevent development of a vigorous understory herbaceous layer and may suppress or kill shade-intolerant savanna species. For sites where the primary goal is restoration of savanna that has developed into woodland or forest, mechanical thinning of stands should be considered as a management tool complementary to prescribed burning. Thinning and removal of harvested trees allows managers to rapidly reduce stand density and basal area, selectively remove individuals based on species and crown morphology, limit accidental damage from falling trees, and reduce future fuel loads.

Another limitation of prescribed burning is in reducing established populations of endurer species, especially shrubs. By monitoring the cover and density of understory trees and shrubs, managers can adjust fire frequencies as needed to suppress these populations. However, if management objectives call for reductions in woody plant populations, prescriptions may need to be altered to include occasional high-severity fires or fires during the growing season (when carbohydrate reserves are low) in an effort to reduce re- sprouting rates in target populations (Waldrop et al. 1992, Glitzenstein et al. 1995).

In general, we believe that efforts to restore degraded oak savannas should begin with annual burning, perhaps coupled with mechanical thinning of stands, to rapidly reduce overstory density and suppress growth of understory shrubs and saplings while a healthy, productive herbaceous layer develops. Mean fire intervals can later be increased to two or more years, using fire as needed to suppress vigor of woody plants. Although this report does not specifically address burning patterns, our results suggest that pattern could be important and that a pattern of two or more consecutive years of burning followed by one or more years without fire could be an effective way to suppress woody plants while reducing the total number of fires.

Long-term persistence of savanna (or open oak woodland) sites requires that a dynamic balance be maintained between mortality and ingrowth, such that neither trees nor grasses become locally extinct. Savannas dominated by resister species like bur oak may be stable over decadal time scales under a high-frequency, low-intensity fire regime that suppresses understory woody plants, prevents ingrowth, and minimizes overstory tree mortality. Long fire intervals are needed, however, to permit occasional ingrowth and to maintain stability at century time scales. Low-frequency fire is ineffective for maintaining savannas on sites with high densities of established woody plants, but might be effective on sites where woody plant establishment and survival is more severely limited by droughts or competition from grasses than in the sandy soils at Cedar Creek. Savannas dominated by endurer species like northern pin oak appear to be structurally unstable under most fire regimes and should probably be managed as dynamic systems with variable fire frequency.

\section{ACKNOWLEDGMENTS}

This project was funded by the Cedar Creek LTER project (NSF Grant DEB-9411972) and graduate fellowships for D. W. Peterson from the University of Minnesota Graduate School. The University of Washington Field Station, USGSBRD, provided additional support for preparation of the manuscript. We thank Cindy Buschena, Peter Bakken, Mark Magnuson, Keith Wrage, and many others for their assistance with field surveys. We also thank L. E. Frelich, M. B. Davis, D. F. Grigal, K. J. Puettmann, K. J. Wrage, D. A. Wedin, D. L. Peterson, D. McKenzie, L. Huenneke, J. Weltzin, and an anonymous reviewer for their helpful comments on earlier versions of the manuscript.

\section{Literature Cited}

Abrams, M. D. 1986. Historical development of gallery forests in northeast Kansas. Vegetatio 65:29-37.

Abrams, M. D. 1992. Fire and the development of oak forests. BioScience 42:346-353.

Agee, J. K. 1993. Fire ecology of Pacific Northwest forests. Island Press, Washington, D.C., USA.

Anderson, R. C., J. S. Fralish, and J. M. Baskin. 1999. Savannas, barrens, and rock outcrop plant communities of North America. Cambridge University Press, Cambridge, UK. 
Belsky, A. J. 1990. Tree/grass ratios in East African savannas: a comparison of existing models. Journal of Biogeography 17:483-489.

Belsky, A. J., R. G. Amundson, J. M. Duxbury, S. J. Riha, A. R. Ali, and S. M. Mwonga. 1989. The effects of trees on their physical, chemical, and biological environments in a semi-arid savanna in Kenya. Journal of Applied Ecology 26:1005-1024.

Bowles, M. L., and J. L. McBride. 1998. Vegetation composition, structure, and chronological change in a decadent midwestern North American savanna remnant. Natural Areas Journal 18:14-27.

Bray, J. R. 1958. The distribution of savanna species in relation to light intensity. Canadian Journal of Botany 36: 671-681.

Callaway, R. M., N. M. Nadkarni, and B. E. Mahall. 1991. Facilitation and interference of Quercus douglasii on understory productivity in central California. Ecology 72: 1484-1499.

Chu, K. L. 1948. The upland plant communities of Cedar Creek Forest, Anoka County, Minnesota. Thesis. University of Minnesota, Saint Paul, Minnesota, USA.

Clark, J. S. 1990. Fire and climate change during the last $750 \mathrm{yr}$ in northwestern Minnesota. Ecological Monographs 60: $135-159$.

Cooper, C. F. 1960. Changes in vegetation, structure, and growth of southwestern pine forests since white settlement. Ecological Monographs 30:129-164.

Cottam, G. 1949. The phytosociology of an oak woods in southwestern Wisconsin. Ecology 30:271-287.

Crow, T. R. 1988. Reproductive mode and mechanisms for self-replacement of northern red oak (Quercus rubra) - a review. Forest Science 34:19-40.

Curtis, J. T. 1959. Vegetation of Wisconsin; an ordination of plant communities. University of Wisconsin Press, Madison, Wisconsin, USA.

Cutter, B. E., and R. P. Guyette. 1994. Fire frequency on an oak-hickory ridgetop in the Missouri Ozarks. American Midland Naturalist 132:393-398.

Dickman, A. 1978. Reduced fire frequency changes species composition of a ponderosa pine stand. Journal of Forestry 76:24-25.

Faber-Langendoen, D., and M. A. Davis. 1995. Effects of fire frequency on tree canopy cover at Allison Savanna, east-central Minnesota, USA. Natural Areas Journal 15 319-328.

Faber-Langendoen, D., and J. R. Tester. 1993. Oak mortality in sand savannas following drought in east-central Minnesota. Bulletin of the Torrey Botanical Club 120:248-256.

Garren, K. H. 1943. Effects of fire on vegetation of the southeastern United States. Botanical Review 9:617-654.

Gleason, H. A. 1913. The relation of forest distribution and prairie fires in the middle West. Torreya 13:173-181.

Gleason, H. A., and A. Cronquist. 1963. Manual of vascular plants of northeastern United States and adjacent Canada. Van Nostrand, Princeton, New Jersey, USA.

Glitzenstein, J. S., W. J. Platt, and D. R. Streng. 1995. Effects of fire regime and habitat on tree dynamics in north Florida longleaf pine savannas. Ecological Monographs 65:441476.

Grigal, D. F., L. M. Chamberlain, H. R. Finney, V. Wroblewski, and E. R. Gross. 1974. Soils of the Cedar Creek Natural History Area. Miscellaneous Report 123, University of Minnesota Agricultural Experiment Station, Saint Paul, Minnesota, USA.

Grimm, E. C. 1984. Fire and other factors controlling the Bigwoods vegetation of Minnesota in the mid-nineteenth century. Ecological Monographs 54:291-311.

Grundel, R., N. B. Pavlovic, and C. L. Sulzman. 1998. Habitat use by the endangered Karner blue butterfly in oak woodlands: the influence of cover. Biological Conservation 85:47-53.

Grunow, J. O., H. T. Groeneveld, and S. H. C. du Toit. 1980. Above-ground dry matter dynamics of the grass layer of a South African tree savanna. Journal of Ecology 68:877889.

Guyette, R. P., and B. E. Cutter. 1991. Tree-ring analysis of fire history of a post oak savanna in the Missouri Ozarks. Natural Areas Journal 11:93-99.

Harmon, M. E. 1984. Survival of trees after low-intensity surface fires in Great Smoky Mountains National Park. Ecology 65:796-802.

Hengst, G. E., and J. O. Dawson. 1994. Bark properties and fire resistance of selected tree species from the central hardwood region of North America. Canadian Journal of Forest Research 24:688-696.

Heyward, F. 1939. The relation of fire to stand composition of longleaf pine forests. Ecology 20:287-304.

Huddle, J. A., and S. G. Pallardy. 1996. Effects of long-term annual and periodic burning on tree survival and growth in a Missouri Ozark oak-hickory forest. Forest Ecology and Management 82:1-9.

Huddle, J. A., and S. G. Pallardy. 1999. Effect of fire on survival and growth of Acer rubrum and Quercus seedlings. Forest Ecology and Management 118:49-56.

Irving, F. D. 1970. Field instruction in prescribed burning techniques at the University of Minnesota. Proceedings of the Tall Timbers Fire Ecology Conference 10:323-331.

Irving, F. D., and S. E. Aksamit. 1983. Tree mortality by fire in oak savanna restoration (Minnesota). Restoration and Management Notes 1:18-19.

Ko, L. J., and P. B. Reich. 1993. Oak tree effects on soil and herbaceous vegetation in savannas and pastures in Wisconsin. American Midland Naturalist 130:31-42.

Leitner, L. A., C. P. Dunn, G. R. Guntenspergen, F. Stearns, and D. M. Sharpe. 1991. Effects of site, landscape features, and fire regime on vegetation patterns in presettlement southern Wisconsin. Landscape Ecology 5:203-217.

McPherson, G. R. 1997. Ecology and management of North American savannas. University of Arizona Press, Tucson, Arizona, USA.

Mordelet, P., L. Abbadie, and J.-C. Menaut. 1993. Effects of tree clumps on soil characteristics in a humid savanna of West Africa (Lamto, Côte d'Ivoire). Plant and Soil 153: $103-111$.

Muir, J. 1913. The story of my boyhood and youth. Houghton Mifflin, New York, New York, USA.

Naumburg, E., and L. E. DeWald. 1999. Relationships between Pinus ponderosa forest structure, light characteristics, and understory graminoid species presence and abundance. Forest Ecology and Management 124:205-215.

Noble, I. R., and R. O. Slatyer. 1980. The use of vital attributes to predict successional changes in plant communities subject to recurrent disturbances. Vegetatio 43:5-21.

Nowacki, G. J., M. D. Abrams, and C. G. Lorimer. 1990. Composition, structure, and historical development of northern red oak stands along an edaphic gradient in northcentral Wisconsin. Forest Science 36:276-292.

Nuzzo, V. A. 1986. Extent and status of midwest oak savanna: presettlement and 1985. Natural Areas Journal 6:6-36.

Parker, V. T., and C. H. Muller. 1982. Vegetational and environmental changes beneath isolated live oak trees (Quercus agrifolia) in a California annual grassland. American Midland Naturalist 107:69-81.

Peterson, D. W. 1998. Fire effects on oak savanna and woodland vegetation in Minnesota. Dissertation. University of Minnesota. Saint Paul, Minnesota, USA.

Pyne, S. J., P. L. Andrews, and R. D. Laven. 1996. Introduction to wildland fire. John Wiley, New York, New York, USA. 
Reich, P. B., M. D. Abrams, D. S. Ellsworth, E. L. Kruger, and T. J. Tabone. 1990. Fire affects ecophysiology and community dynamics of central Wisconsin oak forest regeneration. Ecology 71:2179-2190.

Rowe, J. S. 1983. Concepts of fire effects on plant individuals and species. Pages 135-154 in R. W. Wein and D. A MacLean, editors. The role of fire in northern circumpolar ecosystems. John Wiley, New York, New York, USA.

Sando, R. 1967. The effects of repeated spring burning on the oak stands of the Cedar Creek Natural History Area. Report. University of Minnesota Forestry Library, Sain Paul, Minnesota, USA.

SAS Institute. 1989. SAS/STAT user's guide, version 6. Fourth edition. SAS Institute, Cary, North Carolina, USA.

Scholes, R. J., and S. R. Archer 1997. Tree-grass interactions in savannas. Annual Review of Ecology and Systematics 28:517-544.

Stout, A. B. 1944. The bur oak openings in southern Wisconsin. Transactions of the Wisconsin Academy of Sciences Arts and Letters 36:141-161.

Taft, J. B. 1997. Savanna and open-woodland communities. Pages 24-54 in M. W. Schwartz, editor. Conservation in highly fragmented landscapes. Chapman and Hall, Chicago, Illinois, USA.

Tester, J. R. 1989. Effects of fire frequency on oak savanna in east-central Minnesota. Bulletin of the Torrey Botanical Club 116: $134-144$

Tiedemann, A. R., and J. O. Klemmedson. 1973. Effect of mesquite on physical and chemical properties of the soil Journal of Range Management 26:27-29.

Waldrop, T. A., D. L. White, and S. M. Jones. 1992. Fire regimes for pine-grassland communities in the southeastern United States. Forest Ecology and Management 47: $195-210$.

Weltzin, J. F., and M. B. Coughenour. 1990. Savanna tree influence on understory vegetation and soil nutrients in northwestern Kenya. Journal of Vegetation Science 1:325334

White, A. S. 1981. The effect of different prescribed burning frequencies on species composition in east-central Minnesota. Dissertation. University of Minnesota, Saint Paul, Minnesota, USA

White, A. S. 1983. The effects of thirteen years of annual prescribed burning on a Quercus ellipsoidalis community in Minnesota. Ecology 64:1081-1085.

Whitney, G. G., and J. R. Steiger. 1985. Site-factor determinants of the presettlement prairie-forest border areas of north-central Ohio. Botanical Gazette 146:421-430.

Will-Wolf, S., and F. Stearns. 1999. Dry soil oak savanna in the Great Lakes region. Pages 135-154 in R. C. Anderson, J. S. Fralish, and J. M. Baskin, editors. Savannas, barrens, and rock outcrop plant communities of North America. Cambridge University Press, Cambridge, UK.

Wright, H. A., and A. W. Bailey. 1982. Fire ecology, United States and southern Canada. Wiley-Interscience, New York, New York, USA. 